\title{
Electron trap annealing in neutron transmutation doped silicon
}

\section{Guldberg, J.}

\section{Published in:}

Applied Physics Letters

Link to article, DOI:

10.1063/1.89785

Publication date:

1977

\section{Document Version}

Publisher's PDF, also known as Version of record

Link back to DTU Orbit

Citation (APA):

Guldberg, J. (1977). Electron trap annealing in neutron transmutation doped silicon. Applied Physics Letters, 31(9), 578-579. https://doi.org/10.1063/1.89785

\section{General rights}

Copyright and moral rights for the publications made accessible in the public portal are retained by the authors and/or other copyright owners and it is a condition of accessing publications that users recognise and abide by the legal requirements associated with these rights.

- Users may download and print one copy of any publication from the public portal for the purpose of private study or research.

- You may not further distribute the material or use it for any profit-making activity or commercial gain

- You may freely distribute the URL identifying the publication in the public portal

If you believe that this document breaches copyright please contact us providing details, and we will remove access to the work immediately and investigate your claim 


\title{
Electron trap annealing in neutron transmutation doped silicon
}

\author{
J. Guldberg
}

Institute of Applied Physics III and Laboratory for Semiconductor Technology, Technical University of Denmark, DK-2800 Lyngby, Denmark

(Received 15 July 1977; accepted for publication 19 August 1977)

\begin{abstract}
Silicon doped by neutron transmutation to $1.2 \times 10^{14}$ phosphorus atoms $/ \mathrm{cm}^{3}$ was investigated with deep level transient spectroscopy using evaporated $\mathrm{Au} / n-\mathrm{Si}$ diodes. Seven bulk electron traps were identified which appear after $30 \mathrm{~min} \mathrm{~N}_{2}$ anneal at temperatures between 425 and $725^{\circ} \mathrm{C}$. Five of these annealed in the manner characteristic of intrinsic defects studied by EPR and ir spectroscopy. Two may be related to residual oxygen and carbon complexes.
\end{abstract}

PACS numbers: $61.80 . \mathrm{Hg}, 71.55 . \mathrm{Fr}$

Within the last few years neutron transmutation doping ${ }^{1}$ has been proven a viable technique for producing silicon with extremely high purity and homogeneity. ${ }^{2,3}$ Substantial damage, however, is induced during the irradiation process. Recently Schulz and Lefèvre ${ }^{4}$ concluded that deep level transient spectroscopy ${ }^{5}$ (DLTS) constitutes a particularly useful method for detecting the residual defects in annealed material, but made no attempts to characterize the observed traps. In this work the annealing of electron traps is studied in more details by means of DLTS.

$n$-type dislocation-free float-zone silicon with starting resistivity $>1000 \Omega \mathrm{cm}$ and carbon and oxygen concentrations $<2 \times 10^{16} \mathrm{~cm}^{-3}$ was used in the present study. Doping to a level of $1.2 \times 10^{14}$ phosphorus atoms $/ \mathrm{cm}^{3}$ $(40 \Omega \mathrm{cm})$ was carried out in a thermal nuclear reactor with a thermal-to-fast-neutron flux ratio of $50: 1$, and at a temperature of approximately $135^{\circ} \mathrm{C}$. Wafers cut from the irradiated crystal were etched and subsequent ly polished on one side. After $30 \mathrm{~min}$ anneal in $\mathrm{N}_{2}, 100$ $\mu \mathrm{m}$ was removed from either side of the wafer by chemical polishing in order to suppress surface effects. DLTS measurements were performed on evaporated $\mathrm{Au} / n$-Si diodes $2 \mathrm{~mm}$ in diameter utilizing a standard Boonton $72 \mathrm{~B}$ capacitance meter. The double sampling circuitry ${ }^{6}$ used as the required rate discriminator had a trap detection limit of $0.1 \%$ of background doping. Appropriate corrections were made to account for the time constant of the bridge. ${ }^{6}$

Figure 1 shows the position of the more prominent spectral lines due to majority-carrier traps after an-

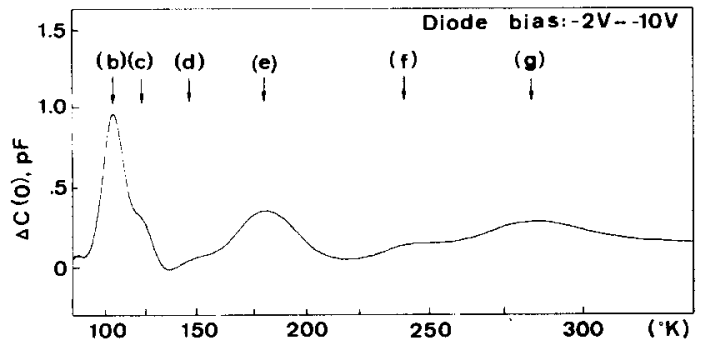

FIG. 1. Electron trap spectrum produced in transmutation doped FZ silicon $(40 \Omega \mathrm{cm})$ after $30 \mathrm{~min} \mathrm{~N}_{2}$ anneal at $500^{\circ} \mathrm{C}$. Emission rate, $180 \mathrm{sec}^{-1}$. Defect labels refer to Table I. neals at $450{ }^{\circ} \mathrm{C}$ or above. Spectra obtained up to $725{ }^{\circ} \mathrm{C}$ all include one or more of these lines with varying amplitudes. Activation energies were determined in the usual manner ${ }^{5}$ of plotting the emission rate $e^{\prime}$ times $(300 / T)^{2}$ versus $1 / k T_{\text {peak }}$. A combined plot for the above defects is presented in Fig. 2. Energy levels and cross sections identified after anneals in the range $425-800{ }^{\circ} \mathrm{C}$ are tabulated in Table I. A few traps, however, which were found in concentrations less than $4 \times 10^{11} \mathrm{~cm}^{-3}$ are not listed. As for (h) it appears to be a surface-generated acceptor-type defect with a diffusion constant of $10^{-8} \mathrm{~cm}^{2} / \mathrm{sec}$ at $500{ }^{\circ} \mathrm{C}$. As usual the activation energies incorporate temperature dependencies in the cross sections and possible Poole-Frenkel effects, therefore the cross sections should only be accepted as a guide line.

Trap concentrations as a function of annealing temperature are illustrated in Fig. 3. Below $425^{\circ} \mathrm{C}$ the defect concentration was so large that free-carrier freeze-out prevented any capacitive measurements. In the temperature range up to $600{ }^{\circ} \mathrm{C}$ the annealing

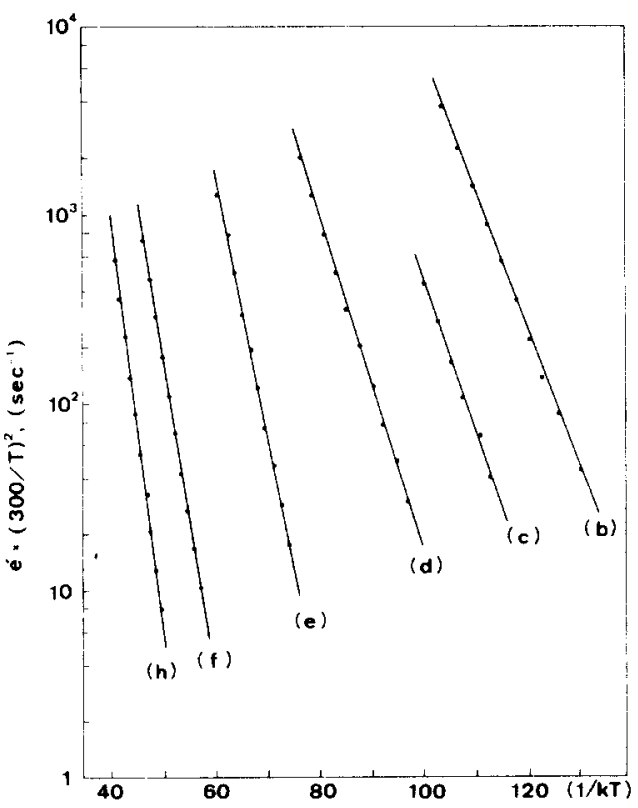

FIG. 2. Arrhenius plot of corrected $e^{\prime}$ values versus $1 / k T$ for defects shown in Fig. 1. 
TABLE I. Electron traps present in neutron-irradiated FZ silicon after $30 \mathrm{~min} \mathrm{~N}_{2}$ anneal.

\begin{tabular}{llll}
\hline \hline & $\begin{array}{l}E_{C}-E_{T} \\
(\mathrm{eV})\end{array}$ & $\begin{array}{l}\text { Cross section } \\
\left(\mathrm{cm}^{2}\right)\end{array}$ & $\begin{array}{l}\text { Temperature range } \\
(\mathrm{C})(\mathrm{min}, \max )\end{array}$ \\
\hline (a) & 0.15 & $2 \times 10^{-16}$ & $\cdots, 450$ \\
(b) & 0.17 & $4 \times 10^{-16}$ & 475,550 \\
(c) & 0.19 & $2 \times 10^{-16}$ & 450,625 \\
(d) & 0.20 & $4 \times 10^{-17}$ & 450,725 \\
(e) & 0.32 & $1 \times 10^{-15}$ & $\cdots, 550$ \\
(f) & 0.40 & $3 \times 10^{-16}$ & 450,525 \\
(g) & 0.46 & $3 \times 10^{-15}$ & $\cdots, 425$ \\
(h) ${ }^{2}$ & 0.50 & $2 \times 10^{-15}$ & 450,525 \\
\hline \hline
\end{tabular}

appears to be a surface effect.

behavior bears strong resemblance to the results obtained by EPR, ${ }^{7}$ i. e. , the disappearance of the $\mathrm{Si}-\mathrm{P}-1$ spectrum between 450 and $500{ }^{\circ} \mathrm{C}$, and also to those of ir absorption spectroscopy, i.e., the generation and disappearance of electronic higher-order bands (HOB) and the complete anneal of band-edge absorption at $550{ }^{\circ} \mathrm{C} .{ }^{9,10}$ Above $750{ }^{\circ} \mathrm{C}$ no defects were detected in agreement with Herzers finding ${ }^{3}$ for reactors with a cadmium ratio larger than $10: 1$.

On this basis it is tempting to associate the (g) level with the pentavacancy responsible for the Si-P-1 spectrum, ${ }^{11}$ (a) and (b) with the two HOB defects, and (e) and (f) with the (vacancy) defects causing the residual band-edge absorption. Unfortunately, structural details which might substantiate these assignments are only available for the pentavacancy and for the HOB defect responsible for the $1102-, 1048-$, and $1124-\mathrm{cm}^{-1}$ resonance lines.

For the pentavacancy the symmetry of the $g$ tensor below room temperature indicates a strong relationship to defects which have primarily one dangling bond in the $\langle 111\rangle$ direction (donor-vacancy complexes) or two parallel $\langle 111\rangle$ bonds (single negative charge of the divacancy). ${ }^{11}$ DLTS data published on the $E$ centers ${ }^{12}$ show levels at $0.44 \mathrm{eV}$ (phosphorus), $0.42 \mathrm{eV}$ (arsenic), and $0.39 \mathrm{eV}$ (antimony), while the energy level 0.41 $\mathrm{eV}$ has been identified for the divacancy. ${ }^{13}$ Hence an activation energy of $0.46 \mathrm{eV}$ for the $(\mathrm{g})$ level and a cross section of $2 \times 10^{-15} \mathrm{~cm}^{2}$, although large, appear not to be unreasonable.

As for the HOB defect it is believed to be a vacancy complex and the resonance lines to be associated with electron transitions between the ground state and a number of excited states. ${ }^{8}$ In this context an activation energy for electron emission of $0.17 \mathrm{eV}$ is quite acceptable for the (b) level.

For the remaining traps (c) and (d) a specific defect assignment is less obvious. Evidence of an oxygenvacancy complex which anneals out at $620^{\circ} \mathrm{C}$ has been given, ${ }^{14}$ but for oxygen-rich material. Also the return of interstitial carbon to substitutional sites at temperatures above $600{ }^{\circ} \mathrm{C}$ is well documented. ${ }^{10,14} \mathrm{In}$ analogy to electron-irradiated silicon this may generate substitutional-interstitial carbon complexes within a certain temperature range. It should be emphasized though that defect interactions at this stage of anneal are poorly

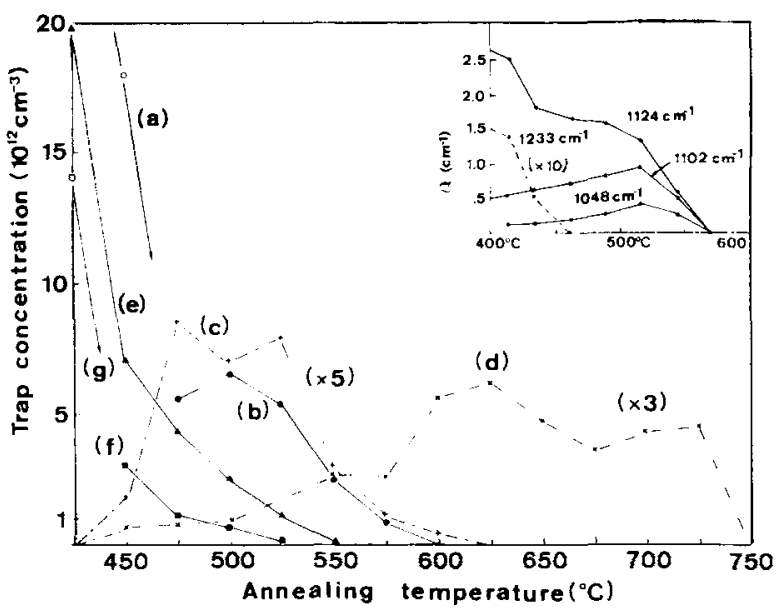

FIG. 3. Annealing of bulk defects in neutron transmutation doped FZ silicon $(40 \Omega \mathrm{cm})$. Inset shows annealing of higherorder infrared absorption bands (Ref. 8).

understood. In particular the factors governing the generation and annihilation of higher-order bands are not sufficiently explored. Moreover Si di-interstitials and interstitial carbon complexes have been identified in $p$-type material, ${ }^{15,16}$ but the role of $S i$ and carbon interstitials in $n$-type material needs further elucidation.

In summary evidence has been presented that electron traps observable with DLTS follow the defect annealing behavior established by other investigations. Furthermore, in those cases where detailed descriptions of defect structures are available, the activation energies derived may be successfully correlated with other defect properties.

The author is indebted to H.M. Janus and O. Malmros for the irradiated wafers.

${ }^{1}$ M. Tannenbaum and A.D. Mills, J. Electrochem. Soc. 108, 171 (1961)

${ }^{2}$ H. M. Janus and O. Malmros, IEEE Trans. Electron Devices ED-23, 805 (1976).

${ }^{3} \mathrm{H}$. Herzer, Semiconductor Silicon 1977 (The Electrochemical Society, Princeton, 1977), p. 106.

${ }^{4} \mathrm{M}$. Schulz and $\mathrm{H}$. Lefèvre, in Ref. 3, p. 142.

${ }^{5}$ D. V. Lang, J. Appl. Phys. 45, 3023 (1974).

${ }^{6} \mathrm{~J}$. Guldberg, J. Phys. E (to be published).

${ }^{7}$ W. Jung and G.S. Newell, Phys. Rev. 132, 648 (1963).

${ }^{8}$ C.S. Chen, R. Vogt-Lowell, and J.C. Corelli, Radiation Damage and Defect Centers in Semiconductors (The Institute of Physics, London, 1973), p. 210.

${ }^{9}$ L. J. Cheng and J. Lori, Phys. Rev. 171, 856 (1968)

${ }^{10}$ R. C. Newman and D. H.J. Totterdell, J. Phys. C 8, 3944 (1975).

${ }^{11} \mathrm{Y}-\mathrm{H}$. Lee and J.W. Corbett, Phys. Rev. B 8, 2810 (1973).

${ }^{12}$ L. C. Kimerling, H. M. DeAngelis, and J.W. Diebold, Solid State Commun. 16, 171 (1975); A.O. Evwaraye, J. Appl. Phys. 48, 1840 (1977); A.O. Evwaraye, J. Appl. Phys. 48, 734 (1977)

${ }^{13}$ A.O. Evwaraye and E. Sun, J. Appl. Phys. 47, 3776 (1976).

${ }^{14} \mathrm{H} . \mathrm{M}$. Liaw and C.J. Varker, in Ref. 3, p. 116.

${ }^{15}$ K. L. Brower, Phys. Rev. B 14, 872 (1976).

${ }^{16}$ K. L. Brower, Phys. Rev. B 9, 2607 (1974). 